\title{
MORPHOTECTONIC ANALYSIS FOR IMPROVEMENT OF NEOTECTONIC SUBDIVISION OF THE LIPTOVSKÁ KOTLINA BASIN (WESTERN CARPATHIANS)
}

\author{
Ladislav Vitovič, Jozef Minár* \\ * Univerzita Komenského v Bratislave, Prírodovedecká fakulta, Katedra fyzickej geografie a geoekológie, \\ Ilkovičova 6,84215 Bratislava, vitovic2@uniba.sk, jozef.minar@uniba.sk
}

\begin{abstract}
Morphotectonic analysis for improvement of neotectonic subdivision of the Liptovská kotlina Basin (Western Carpathians)

The Liptovská kotlina Basin (LKB) belongs to the most neotectonically active intramountain basins of the Western Carpathians (Halouzka 1993). Its last neotectonic subdivision was carried out at the scale 1:200,000 (Halouzka 1993), later included in the Neotectonic map of Slovakia (Maglay et al. 1999). This paper presents a more detailed subdivision and delineation of borders of neotectonic blocks of the LKB on the basis of the set of morphotectonic analyses. The Váh River terraces, thickness of Quaternary deposits, faults and morpholineaments and SL index were employed to more precisely delimitate the neotectonic blocks. A long profile analysis of the river terraces bedrock (inferred from 127 drillings and outcrops) and bedrock surface of the recent floodplain (65 drillings) was carried out to detect neotectonic faults within the fluvial systems. Based on the relative height of the surfaces under a terrace and previous fluvial sediment investigations (e.g. Droppa 1964 and Gross 1979), eleven terrace levels were confirmed. 1,958 boreholes and 1,085 geophysical points were used to identify the spatial distribution of the thickness of the Quaternary fill of the basin. Tectonic faults and morpholineaments were used as borders of particular neotectonic blocks. Suggesting the alternation of neotectonic borders, the LKB was subdivided into 60 neotectonic blocks comparing to 24 blocks of former subdivisions (Maglay et al. 1999). Moreover, a new Quaternary depression filled with glacifluvial deposits was identified (min $50 \mathrm{~m}$ of thickness) in close vicinity to Pribylina, which could be added to the depressions list (Maglay et al. 2011a).
\end{abstract}

Key words: river terraces, morphotectonics, neotectonic subdivision, Liptovská kotlina Basin, Western Carpathians

\section{INTRODUCTION}

The geomorphological subdivision of Slovakia is generally based on the morphological and lithological differences that are clearly relative to neotectonic differentiation on the level of "geomorphological units" (Mazúr and Lukniš 1978 and Bandura et al. 2017). The levels of "geomorphological subunits" and mainly "parts" are more ambiguous (including exogeneous features) and less systematic. The traditional subdivision is in this case challenged by methods of morphostructural (e.g. Lacika 1993 and 1997) or morphotectonic analysis (e.g. Beták and Vojtko 2009). The neotectonic subdivision of Slovakia (Maglay et al. 1999) represents a regionalization deeply wedded with geomorphological division, however with specific features in methodology and content. On the one hand it ignores morphological differences not expressing a neotectonic movement, on the other hand, a part of neotectonic boundaries can be masked by sedimentary cover (so not reflected in relief). Methodologically, the neotectonic subdivision should use all relevant methods and results of morphotectonic analysis (Urbánek 2001 and Kvitkovič 2001). 
The importance of neotectonic studies was mentioned in several papers (e.g. Halouzka et al. 1999 and Fodor et al. 2005) and the neotectonic structure of a landscape (neotectonic subdivision) can be calculated several ways using certain level of details (e.g. Zuchiewicz 1998, Maglay et al. 1999, Fodor et al. 2005 and Vojtko et al. 2012). The previous neotectonic regionalisation of the Liptovská kotlina Basin (LKB) was carried out in the scale 1:500,000 (Maglay et al. 1999) using and improving the previous subdivision of the Podtatranská kotlina Basin (Halouzka 1993). Considering the reasonable size of the LKB $(\sim 60 \times 15 \mathrm{~km})$, a more detailed regionalisation could be carried out, using a wider set of morphotectonic analyses. The long profile of Váh river terraces, thickness of Quaternary deposits, stream length-gradient index (SL), spatial distribution of travertines and faults and morpholineaments analyses were used in this study. The main output of the paper is a more detailed subdivision and delineation of new borders of neotectonic blocks of the LKB, which contributes to the better recognition of the morphotectonic evolution of the area.

\section{REGIONAL SETTINGS AND STATE OF THE ART}

The Liptovská kotlina Basin (Fig. 1) is about a $60 \mathrm{~km}$ long and 5 - $15 \mathrm{~km}$ wide depressional intramountain morphostructure. LKB belongs to the Fatra-Tatra region and the Podtatranská kotlina Basin unit (as one of its three subunits). Internally it is divided into seven geomorphic parts (senzu Mazúr and Lukniš 1978, see Fig. 1). According to the new morphostructural subdivision of the Western Carpathians (Minár et al. 2011), the LKB belongs to the Central Region and Tatra Subregion. Its morphology - basin hilly land - rises from $467 \mathrm{~m}$ to $1,018 \mathrm{~m}$ a. s. 1 . The valley of the Váh River (comprising the Biely Váh and Čierny Váh Rivers) is the main axis of the LKB. The river forms from the confluence of the Biely Váh River (sourcing in the Tatry Mts.) and the Čierny Váh River (sourcing in the Nízke Tatry Mts.).

The main tributary of the Váh River within the LKB is the Belá River (rightbank tributary sourcing in the Tatry Mts.). The average discharge of the Váh River in Ružomberok (outlet from the basin) is $37.5 \mathrm{~m}^{3} / \mathrm{s}$ (Abaffy and Lukáč 1991).

The basement of the LKB is formed by the inner-Carpathian Paleogene (Upper Priabonian to Lower Oligocene) underlaid by Tatric (Paleozoic/Mesozoic), Fatric and Hronic sedimentary rocks (Mesozoic). After the Paleogene sea regression (at the end of the Oligocene age), the LKB is assessed to have terrestrial georelief development with the drainage system formation. Fluvio-limnic sediments in the uppermost morphopositions in the terrace system (in central part of the LKB) are considered to be from the Pliocene age (Droppa 1964 and 1972, Vaškovský 1970 and 1980 and Remšík et al. 1993). The age and thickness of the Quaternary deposits of diverse genesis (mainly travertines and fluvial deposits) are the important stratigraphic marker of the LKB (Vaškovský 1980).

Together with the Tatry Mts. and the Popradská kotlina Basin, the LKB is considered to be neotectonically the most active region within the Slovak part of the Carpathians (Halouzka 1993). Boundaries with adjacent mountains and the Popradská kotlina Basin are controlled by Quaternary active faults (Maglay et al. 1999). The Choč-Subtatric fault is the most expressive tectonic fault separating the LKB from the Chočské vrchy Mts. and Tatra Mts. Vertical dislocation of the LKB against the Chočské vrchy Mts. is $1-2 \mathrm{~km}$ (Ondrášik 1987). According to Biely et 
al. 1997, the vertical dislocation along the border fault between the LKB and the Nízke Tatry Mts. (near to village Pavčina Lehota) is more than $1,000 \mathrm{~m}$. Unfortunately, no time span was given to the tectonic movements by the mentioned authors. There has been a vertical movement along the Subtatric fault (since Panonian) reaching ca. $400 \mathrm{~m}$ according to Vaškovský (1975). A similar, but only Quaternary, uplift (300-400 m) is determined for the Tatra Mts. by Lukniš (1973). Quaternary activity of the Choč-Subtatric fault (along the Západné Tatry Mts. foothill) is estimated to be at least $50 \mathrm{~m}$ (Halouzka et al. 1999). Quaternary active faults within the whole LKB are delineated in the Neotectonic Structure Map of Slovakia (Maglay et al. 1999) and the Quaternary Geological Map of Slovakia (Maglay et al. 2011b).

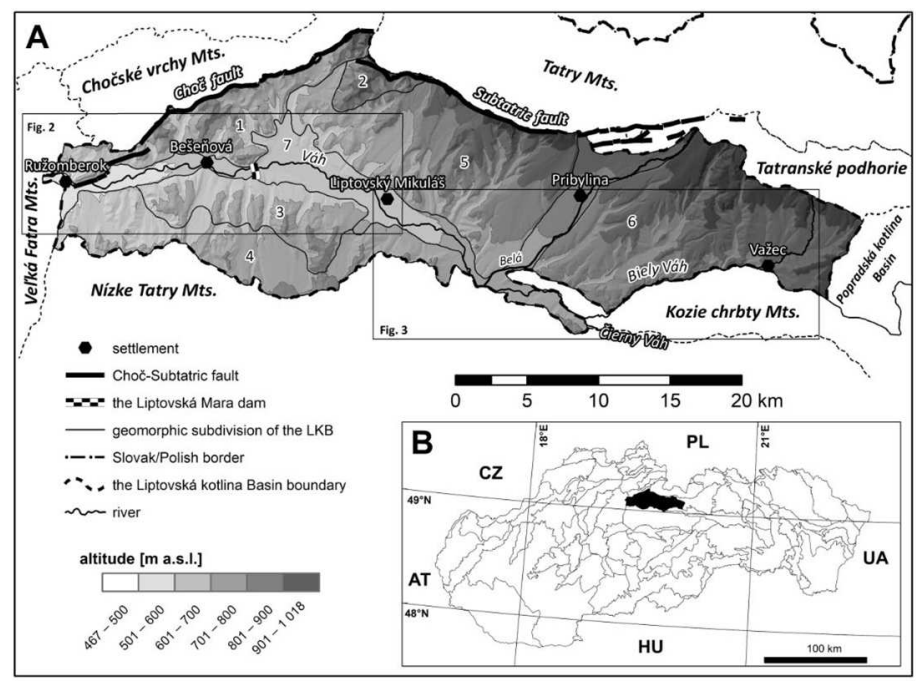

Fig. 1. A. Shaded hypsometric map of the Liptovská kotlina Basin. Numbers refer to geomorphic parts: 1 - Chočské podhorie, 2 - Matiašovské háje, 3 - Galovianske háje, 4 - Lubelská pahorkatina, 5 - Smrečianska pahorkatina, 6 - Hybianska pahorkatina, 7 - Liptovské nivy. B. The location of the study area within geomorphological units of Slovakia. Geomorphological parts and units after Mazúr and Lukniš 1978 in terms of Urbánek et al. 2009

The faults dissect the basin into several separate blocks with various vertical and horizontal movement tendencies (Gross 1980 and Halouzka et al. 1999). Gross (1980) considers E-W faults as older and N-S as younger. According to Halouzka (1987), two types of directions of Quaternary active faults in the eastern part of the LKB can be distinguished: N-S (older) and NE-WS (or ENE-WSW, younger one). The same classification can be recognized in the entire basin for neotectonically active faults (Halouzka et al. 1999). Littva (2017) distinguishes three main directions of neotectonic failures: NNE-SSW, NE-SW and NW-SE, and two phases of Pliocene - Quaternary tectonics. The first one is the activity along the EW and NE-SW normal faults as a response to the NW-SE to NNW-SSE extension and the second is activity along transversal faults connected with the E-W to ESEWNW extension. Dating of neotectonic change of the stress field is unclear, but the Lower Pleistocene Age is the most probable (Littva and Hók 2014 and Littva 2017). 
Travertine accumulations present significant evidence of the active tectonics. According to previous studies, the travertine deposits (Pleistocene and Holocene age) are located predominantly in the western part of the LKB (for instance in Bešeňová, Lúčky and Ludrová villages) - Vaškovský and Ložek (1972) and Vaškovský (1980).

According to the previous neotectonic investigations, the LKB was divided into 24 partial blocks predominantly subsiding during the Quaternary (Halouzka 1987 and 1993 and Maglay et al. 1999). The position of fluvial terraces and paleogeographical changes in drainage network were used to assess the role of neotectonics in the LKB (Halouzka 1987).

River terraces of the Váh River and its tributaries as well as their distribution asymmetry and tectonic dislocations were studied mainly in the central and western part of the LKB (Droppa 1963, 1964, 1970 and 1972 and Pešková and Hók 2008). The research of the relationship and evolution of terraces and horizontal cave system (in Demänovská valley) was performed mainly by Droppa (1963 and 1966) and Bella et al. (2011 and 2014). River terraces were investigated also by Vaškovský and Ložek (1972), Vaškovský (1970 and 1975), which were compiled to the geological map of the LKB (Gross 1979). River terraces were studied by Vaškovský (1980) - the majority of the area of the LKB, Maglay (1993) - in the NE vicinity of Ružomberok, Halouzka et al. (1997) - in the surroundings of the confluence of the Biely Váh and Čierny Váh Rivers, Pristaš (1997) - in the SW vicinity of Ružomberok and Banský and Tužinský (1971) - the majority of the area of the LKB. Within the engineering-geological research (at scale 1:10,000), the fluvial sediments were studied by Páleník (1988) and Vráblová et al. (1990). Based on morphoposition and weathering of the fluvial material, the Váh River terraces were divided into four groups: low (3 levels), middle (2), high (3) and preQuaternary (3) - Droppa 1964 and Vaškovský and Ložek, 1972. The latter authors note, that there are ca. $2-3$ of low levels and $3-4$ pre-Quaternary terraces. A similar system of terraces was described by Droppa (1970) and Vaškovský (1975 and 1980), only with the difference in number of high (4 levels) and preQuaternary terraces. According to Halouzka et al. (1997), the terraces of the Váh and Biely Váh Rivers were divided into low (3 levels), middle (3), upper (2), high (3) and plateau (2 levels) terraces. Recent floodplain and Holocene terrace was included in the low terraces groups. Erosion downcutting of the Váh River during the Quaternary period was assessed to be $100 \mathrm{~m}$ by Droppa (1964), Vaškovský and Ložek (1972) and even more than 110 m by Vaškovský (1970).

The Quaternary deposits thickness, channel pattern changes of the Belá River and faults strikes were studied by Nešvara (1970) to reveal neotectonic movements in the central part of the LKB. The spatial distribution of Quaternary deposits thickness was evaluated for the whole LKB by Maglay et al. (2009).

\section{MATERIALS AND METHODS}

In order to estimate the boundaries of partial neotectonic blocks of the LKB, an integrated approach was taken. It consists of the study of the previous research of the neotectonic structure of the LKB (Maglay et al. 1999) and several partial analyses (relative height of fluvial terraces, thickness of Quaternary deposits, SL (stream length-gradient) index, faults and morpholineaments delineation, regarding 
the morphology of recent georelief) and their correlation for the purpose of the new neotectonic regionalisation of the LKB.

\section{Terrace system analysis}

We have focused on the Váh, Biely Váh and Čierny Váh River terraces only because of the lack of boreholes in the terraces (or alluvial fans) of its tributaries. The information about remnants of fluvial terraces (age and position) was derived mainly from the investigations of Gross (1979) and Droppa (1964, 1970 and 1972). The position of selected remnants was compared to the research of Sladký (1938), Vaškovský (1970), Banský and Tužinský (1971), Páleník (1988), Vrábl’ová et al. (1990), Halouzka et al. (1997), Littva (2017) and own field survey as well. Based on contour and topographic maps (contour interval 2 and $5 \mathrm{~m}$ ), terrace treads were manually drawn in GIS software regarding the previous studies. The altitudes of the terraces' bedrock surfaces were identified from the boreholes database and our own and previous field research (Droppa 1964, 1970 and 1972). The altitude of bedrock surface was in several cases derived also from the alluvial fans located in close vicinity to the Váh River, presumed it's reflecting a particular river level of the valley floor. Within this paper, only the accumulation levels with separate bedrock surfaces with fluvial cover were considered. Strath terraces remain unrecorded. To obtain the relative height of terraces' bedrock, the altitudes were related to the altitude of the current floodplain. The altitude of the floodplain was derived from a Topographic map $(1: 25,000)$, used as a WMS layer. The longitudinal profiles of fluvial systems were constructed in Microsoft Excel.

\section{Thickness of Quaternary deposits}

The thickness and type of sediment information was derived from the borehole and geophysical database. The database was obtained from the archive of the State Geological Institute of Dionýz Štúr (SGIDŠ) in the form of a Microsoft Access Database (mdb.). First ca. 300 boreholes contained GPS coordinates, borehole description, Quaternary/pre-Quaternary boundary depth information, etc. Consequently, additional points with known Quaternary deposits thickness were added to the database, resulting in 1,958 boreholes (hydrogeological, engineering-geological, drillings of wells) and 1,085 points from geophysical profiles (VES and ERT techniques, predominantly localities of electrodes). Reports of investigations (stored in the archive of the Geofond of SGIDS) were the source of the information. The deposits thickness map was prepared with the "Topo-to-raster" interpolation method (interpolated totally 3,043 points) in ArcGIS 10.5 software. The research focused mainly on recent and paleostream accumulations (fluvial and glacifluvial deposits), as a tectonic activity takes control over the distribution of erosion and deposition processes (Keller and Pinter 2002).

\section{SL (stream length-gradient) index analysis}

The SL index was calculated for the Biely Váh, Čierny Váh and the Váh Rivers and its main tributaries in according to Hack (1973):

$$
S L=L . \frac{\Delta H}{\Delta L},
$$

where $S L$ - stream length-gradient index, $\Delta H$ - change in elevation of reach $(5 \mathrm{~m}$ in this study), $\Delta L$ - length of the reach (between two contour lines in this study), 
$L$ - total upstream length of the channel from the point where the value of index is calculated to the basin divide.

The SL index values were computed in ArcGIS 10.5 software. The Topographic map 1:25,000 as a WMS layer was used to obtain the elevation and position of particular information. The index value was assigned to the midpoint of each segment between two contour lines and subsequently interpolated using the Inverse Distance Weight interpolation method. The resulting raster was extracted by vector mask representing a $200 \mathrm{~m}$ buffer zone along the streams.

Faults, morpholineaments and river network delineation

Selected tectonic faults and morpholineaments were used as borders of neotectonically active blocks of the LKB. Faults were adapted from previous geological and geophysical research of diverse scales (Nešvara 1970, Gross 1979, Páleník 1988, Vrábl’ová et al. 1990, Szalaiová et al. 1991, Hrašna 1997, Maglay et al. 1999, Szalaiová et al. 2008, Maglay et al. 2011b and Littva 2017). Reflecting the fault activity, the mylonit and ultramylonit zone ( $9 \mathrm{~m}$ broad) was identified in the Liptovská Mara dam area (Stolečňan 1975). The faults from more detailed investigations were preferred as the blocks boundaries.

According to geological profiles sketches, based on selected geophysical investigations (Janík 1970a and b and Suchý 1986), new potential tectonic faults were recognized.

Morpholineaments were manually drawn following the linear parts of drainage network, foothill lines and expressive terrain scarps on the bases of digital terrain model (DTM) and contour lines (in scale 1:50,000). In cases where the markers of neotectonics (mentioned above) were present, but no tectonic line was found according to the previous research in that line area, morpholineaments as block boundaries were used.

River network and streams orders were generated in ArcGIS 10.5 environment using a Hydrology toolbox.

\section{Travertines}

Travertine deposits are located along a fracture trace, immediately above the extensional fissure or in the hanging wall of a normal fault (Hancock et al. 1999). The deposits were used to reveal neotectonic activity within the LKB region. Travertines were taken from geological (Ivan 1943, Droppa 1975 and Gross 1979) and engineering-geological maps (Páleník 1988 and Vrábl'ová et al. 1990) and consequently visualised as a point layer categorized on the basis of their age. Their age was determined from their position on river terraces (Droppa 1972), a paleontological investigation (Vaškovský and Ložek 1972 and Vaškovský 1980), stabile carbon and oxygen isotopes value dating (Franko 2001), U-Th dating (Gradziński et al. 2008) and paleomagnetism (Gradziński et al. 2015).

\section{Revision of the neotectonic subdivision}

To create a more detailed neotectonic division of the LKB, the previous neotectonic investigations and results of partial analyses were compared and correlated. We identified the basic blocks delineated according to Maglay et al. (1999) and subsequently made a more detailed division of the blocks. More detailed delimitation was based on two basic steps: a) correction of former border lines, and b) interior dividing the blocks. 
The first step (correction of border lines) relates to preferring faults mapped on a larger scale or morpholineaments as block borders. In the case of internal heterogeneity (according to used markers), the neotectonic blocks were divided in the second step. The procedure of the division of the blocks was based on detailed tracing of neotectonic markers analyses, regarding the recent morphology. The presence of neotectonically active faults was estimated on the basis of the SL index or other markers of neotectonics strictly above or near the fault or morpholineament lines. In some cases, the prolongation of faults not expressed in morpholineaments were used as borders too. The morpholineaments were preferred in the case of the close vicinity of mapped faults. According to the terraces analysis, relatively uplifted and subsided areas (with different intensities) were identified along the main rivers.

Areas (mainly limited by natural morphology) with different thickness of fluvial or glacifluvial deposits along the fault line (or morpholineament) were considered as evidence of neotectonic activity. Faults, in the map crossing the travertines and vertically dislocating terraces remnants were considered to be neotectonically active as well.

\section{RESULTS}

\section{Terrace system}

Terrace remnants of the Váh River and its sources, the Biely Váh and Čierny Váh Rivers, were localized within the LKB from Važec to Ružomberok (Figs. 2, 3 ). They are mostly of the composite type (composed of alluvial deposits and bedrock). Only the low terrace presents the accumulation type eroded into three erosional steps (Droppa 1964, Vaškovský 1980). The state of the preservation or absence of the terraces changes along the rivers. Four significantly different segments can be distinguished along the main valley in the LKB. Within these segments the state of the preservation of terraces and the width of the floodplain changes. Inside the first segment between the Važec and the confluence of the Biely Váh and Čierny Váh Rivers, the right-bank terraces are better preserved. The width of floodplain reaches $\sim 20-260 \mathrm{~m}$ (Fig. 3). Mainly narrow and elongated remnants of terraces occur in the second segment (from the confluence of the Biely Váh and Čierny Váh Rivers to town of Liptovský Mikuláš), which is characterised by a lack of right-bank terraces. Medium-wide and several elongated remnants are located within this segment. The range of floodplain is $\sim 60 \mathrm{~m}$ (SE segment) $-2,000 \mathrm{~m}$ (NW segment). The widest and well preserved terraces on the both sides of the valley can be found within the third segment between town Liptovský Mikuláš and the Liptovská Mara dam. While the entire terrace system is preserved on the left bank, the right bank is characterised mainly by the middle terrace system preservation. The width of the floodplain is relatively homogenous ranging from $\sim 1,200$ to $2,000 \mathrm{~m}$. Along the last segment (from the Liptovská Mara dam to the Vel'ká Fatra Mts.) the left-bank terraces remain predominantly preserved. Here, the Váh River passes two relatively narrow valley segments (in the area of the Liptovská Mara dam and $\mathrm{W}$ of Ružomberok) resulting in a changing floodplain width $(\sim 200-$ $1,600 \mathrm{~m}$ ). Eleven levels of river terraces (including recent floodplain) were identified on the basis of the relative height of terraces' bedrock surfaces (Figs. 2, 3 and 4), which were identified in 192 boreholes. Terraces are presumed to be from the Upper Pliocene to the Holocene age (Droppa 1964 and 1972, Gross 1979 and Vaškovský 1980). Some of the plateau terrace remnants are formed by fluvio- 
limnic sediments, while the rest of the terraces consist of fluvial or glacifluvial sandy gravel to gravel often covered with eluvial-colluvial or loess loam (Gross 1979). The vertical tectonic dislocation of several terraces results in their higher or lower position (Fig. 4). For example, an uplifted remnant of a terrace occurs ESE of Ružomberok, while the subsided remnant is located NW of Liptovský Mikuláš. The remnants at both localities are dislocated by faults with NNE-SSW directions. The wind gap feature was identified E of Ružomberok, where fluvial accumulation (1. upper terrace, 3. high terrace according to Maglay 1993) is located in a horstlike elevation (structure).

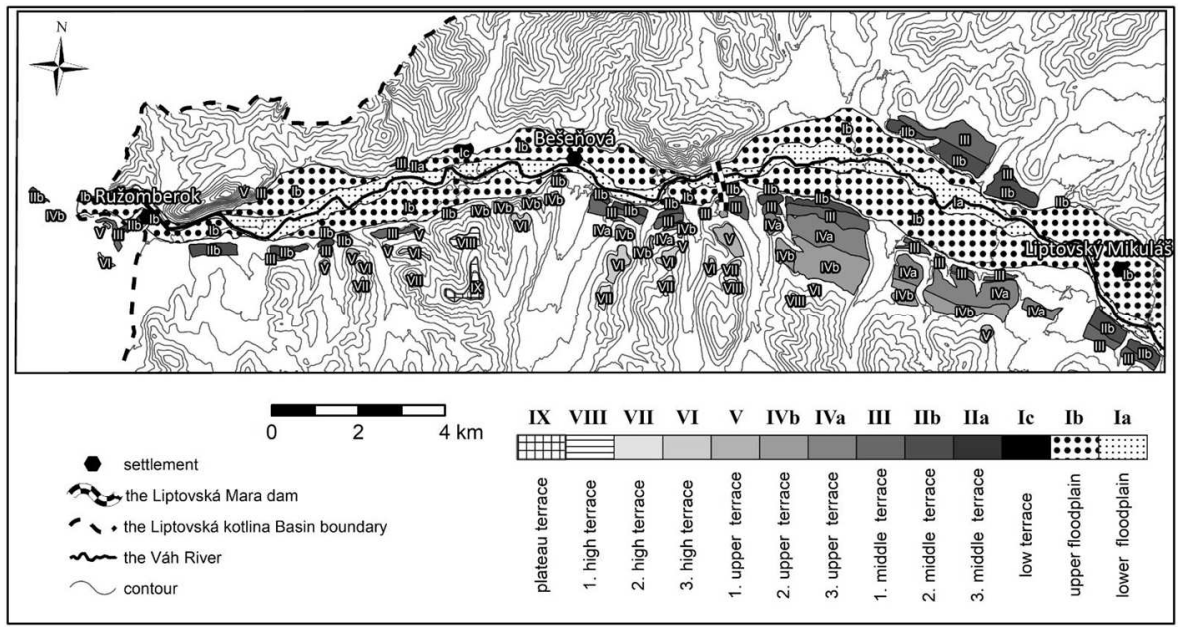

Fig. 2. Terrace system in the western part of the Liptovská kotlina Basin

Contour interval 20 m. Compiled using Droppa (1964 and 1972), Gross (1979), Páleník (1988), Vrábl'ová et al. (1990), Maglay (1993), Pristaš (1997) and own field research.

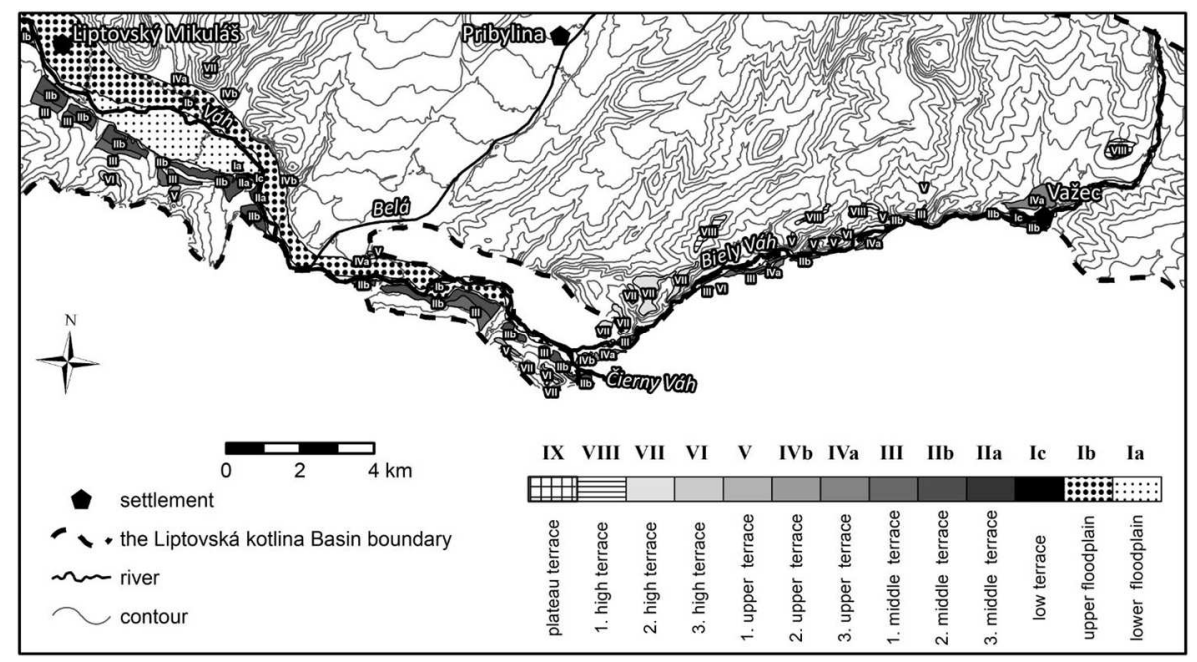

Fig. 3. The Váh River terrace system in the eastern part of the Liptovská kotlina Basin Contour interval 20 m. Compiled using Droppa (1964), Gross (1979), Páleník (1988), Vráblová et al. (1990), Halouzka et al. (1997) and own field research. 


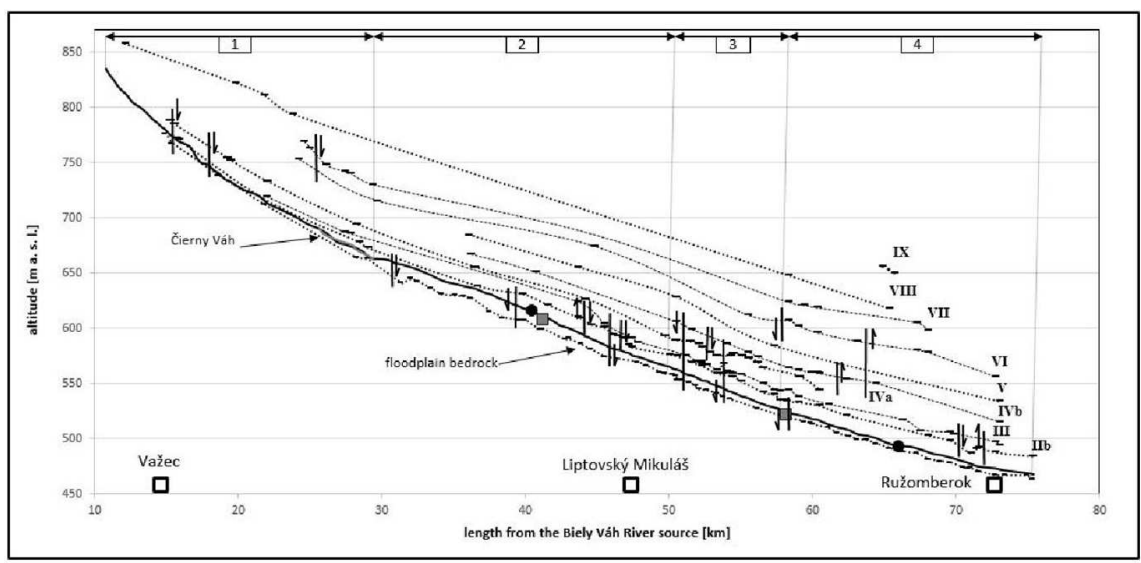

Fig. 4. Long profile of the Biely Váh River (black line until the confluence with the Čierny Váh River), Čierny Váh River (gray line) and the Váh River thalwegs and bases of their terraces (Roman numerals, see Figs. 2, 3). The black dots represent the base of the $3^{\text {rd }}$ middle terrace, gray squares the base of low terrace remnants. Segments mentioned in the text are shown above the profile (Arabic numerals). Probable relative uplift and subsidence are expressed by half-arrows

\section{Thickness of Quaternary deposits}

Thickness of Quaternary deposits significantly varies within the LKB (Fig. 5). The mean thickness value is $7 \mathrm{~m}$. Minimum values (around $0.2-3 \mathrm{~m}$ ) tend to relate to thin slope regolith. Maximum values $(79 \mathrm{~m})$ are linked with glacifluvial sediments in the NE part of the LKB. Generally, the sites with high values are located predominantly to the N and NW of the Važec (glacifluvial fans), along the Belá River (fluvial and glacifluvial sediments) and along the Váh River (floodplain and terrace sediments).

A relatively large depression (in average ca. $1-2 \mathrm{~km}$ wide) filled with glacifluvial sediments (water-bearing gravels, boulders and sandy gravels) was identified S -W of Pribylina (Fig. 5). The depression was located with a geophysical and drillings survey (Košecký 1968, Janík 1970b and Tužinský et al. 1971). According to the geophysical research, the maximal depth of the basement was assessed to $\sim 80$ m (Košecký 1968) or even 100 m (Janík 1970b). The deepest borehole in this area $(50 \mathrm{~m})$ did not reach the basement (Tužinský et al. 1971). Based on the latest engineering-geological survey (Vrábl'ová et al. 1990), the extent of the depression was partly delimited (mainly on the $\mathrm{W}$ part). The age of filling material was assessed be from the Riss glacial period (Tužinský and Banský 1968).

Changes in the thickness of the floodplain accumulation could reveal potential relative uplift and subsidence. The Váh River reach from $31 \mathrm{st} \mathrm{km}$ to 45 th $\mathrm{km}$ (Fig. 4) has a significant floodplain deposits thickness (ca. 10-16 m), while the thickness of floodplain deposits of the river reach within the last quarter of the LKB is markedly lower (ca. $3-5 \mathrm{~m})$. 


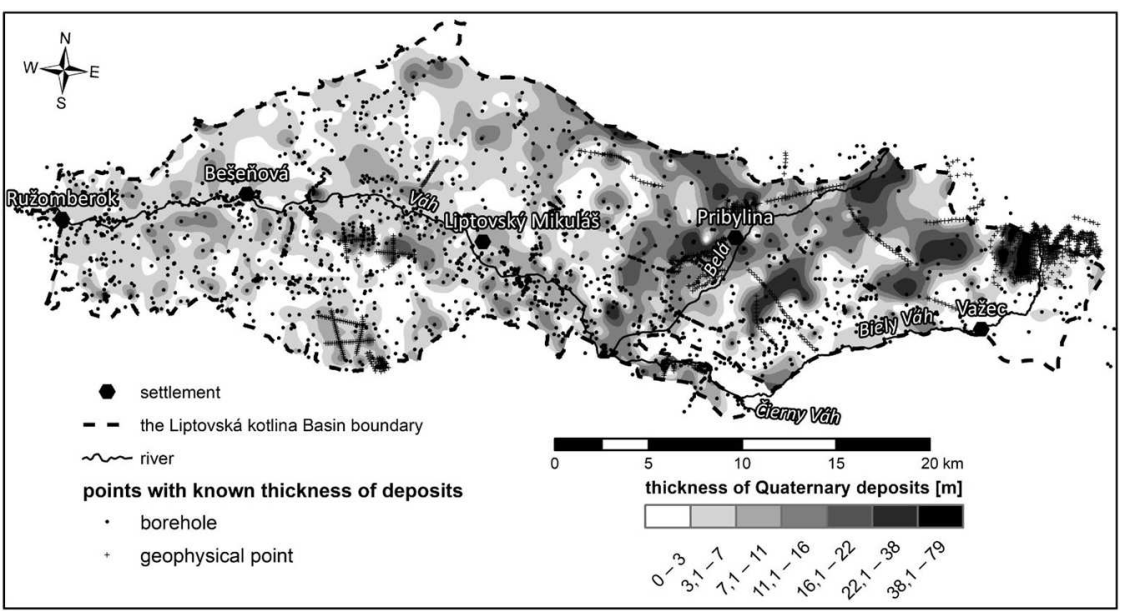

Fig. 5. Isopach map of the Quaternary deposits

SL (stream length-gradient) index

The SL values are highly variable with a range from 3 to 1,301 (Fig. 6). To detect the potential active tectonics within the LKB, the local relative increases of the values were taken into account. In general, many sites with an increased SL value occur on the LKB boundaries with the adjacent mountains as it is conditioned by the different lithology, and the brittle tectonics. There are also several reaches along the valleys inside the LKB. Examples of locations, where the SL index helped in the subdivision process can be found (Fig. 6).

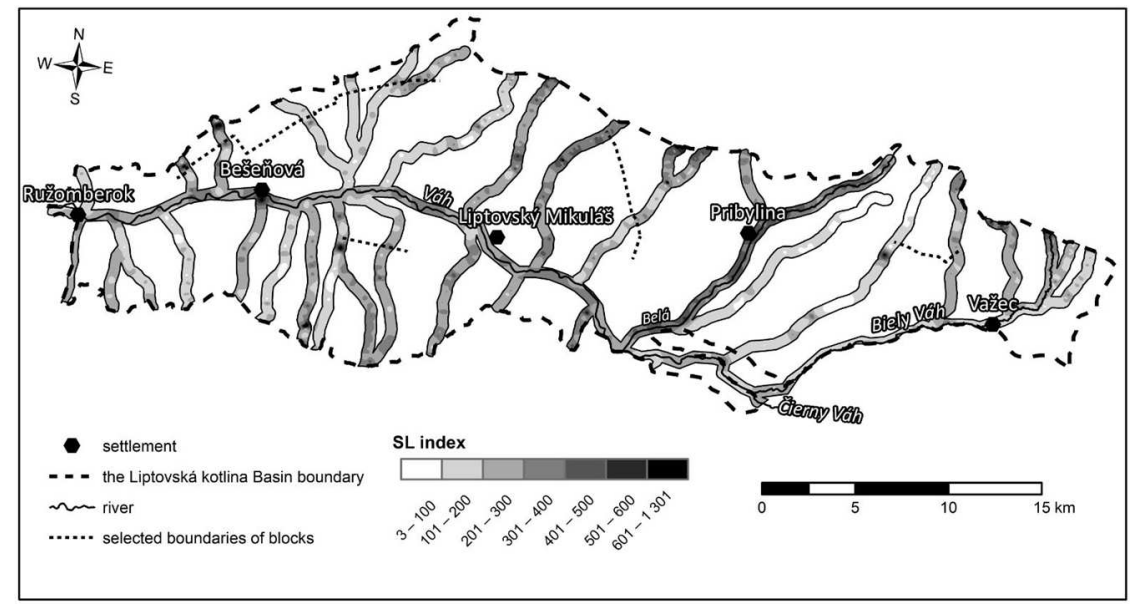

Fig. 6. SL index values and selected boundaries of neotectonic blocks (as the examples where SL index helped in subdivision process) within the Liptovská kotlina Basin 
Faults and morpholineaments

Tectonic faults of the LKB were mapped at various scales (Fig. 7) by different authors. They tend to extend along the borders with adjacent mountains, as well as along the terrain scarps and valleys. Closely spaced parallel faults mapped by various authors might be actually various interpretations of the same real failure. The age and punctuality of mapping as well as conformity with morpholineaments were the criteria for the selection of a block delimiting line in such a case.

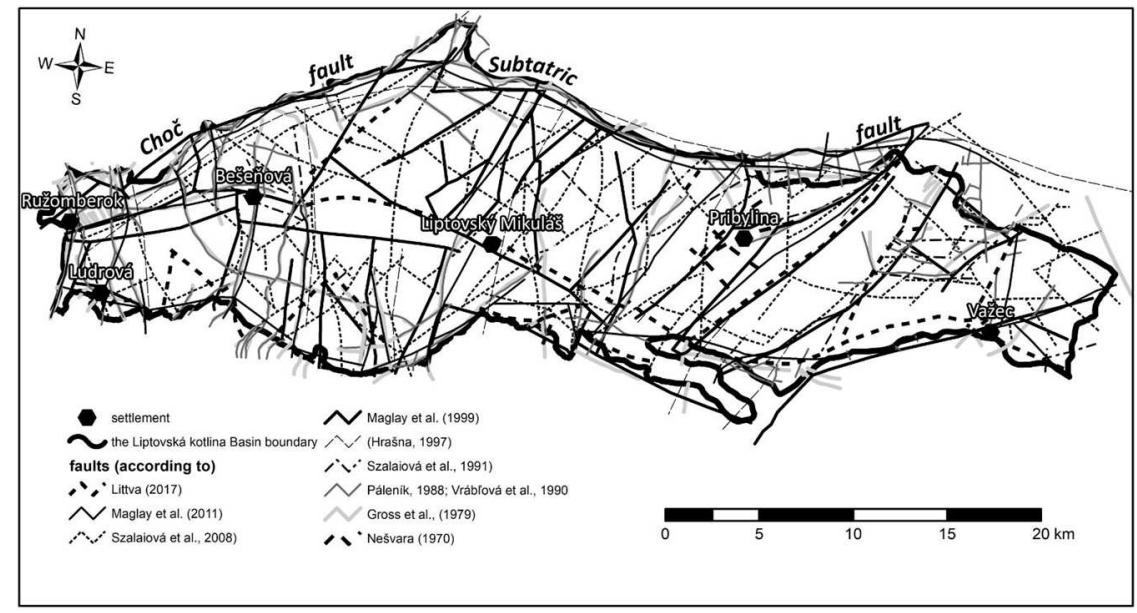

Fig. 7. Tectonic faults of the Liptovská kotlina Basin according to the previous studies (see legend)

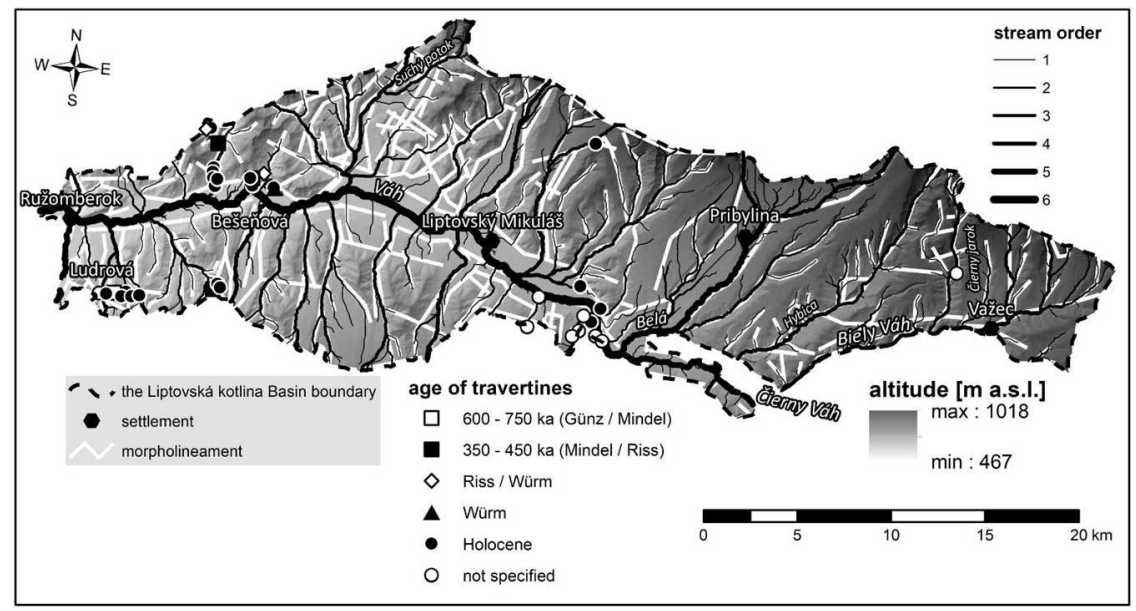

Fig. 8. Travertines, morpholineaments and streams according to Strahler order (Strahler 1952) of the Liptovská kotlina Basin (age of travertines is referred in the text). 
The majority of morpholineaments occur along the borders of the LKB and river valleys of the Váh River tributaries (perpendicular to the Váh River) and along the main valley floodplain foothill (Fig 8). The predominant direction of the morpholineaments is N-S (left bank of the Váh River) and NE-SW (right bank of the Váh River). In the eastern part, the frequent lineament direction is also N-S.

The river network within the LKB consists of six orders (senzu Strahler 1952), as the vast number of streams rise in adjacent mountains. The asymmetry of part of the river network can be considered as the most distinctive feature of river texture (e.g. streams Suchý potok, Hybica and Čierny jarok, Fig 8).

\section{Travertines}

Travertines of different types (calcareous tufas, cavern limestones and massive travertines) from the Pleistocene (mainly interglacials) to the Holocene age (Franko 2001, Gradziński et al. 2015, Vaškovský and Ložek 1972, Vaškovský 1980) are located predominantly in the western and central part of the LKB (Fig. 8). They occur in the close vicinity of the important faults and morpholineaments that are natural boundaries of the basin or its basic parts. The oldest ones lie in its western portion. The Čerená travertine (in Ludrová village) dates back to $750-600 \mathrm{ka}$ (Franko 2001) and Bešeňová (inactive quarry) between 750 - 350 ka (Gradziński et al. 2015), or 450 - 350 (Franko 2001). All the travertines are presumed to be interglacial, only the Drienok (E of Bešeňová, at its foothill) is presumed to be of glacial (Würm) origin (Vaškovský and Ložek 1972).

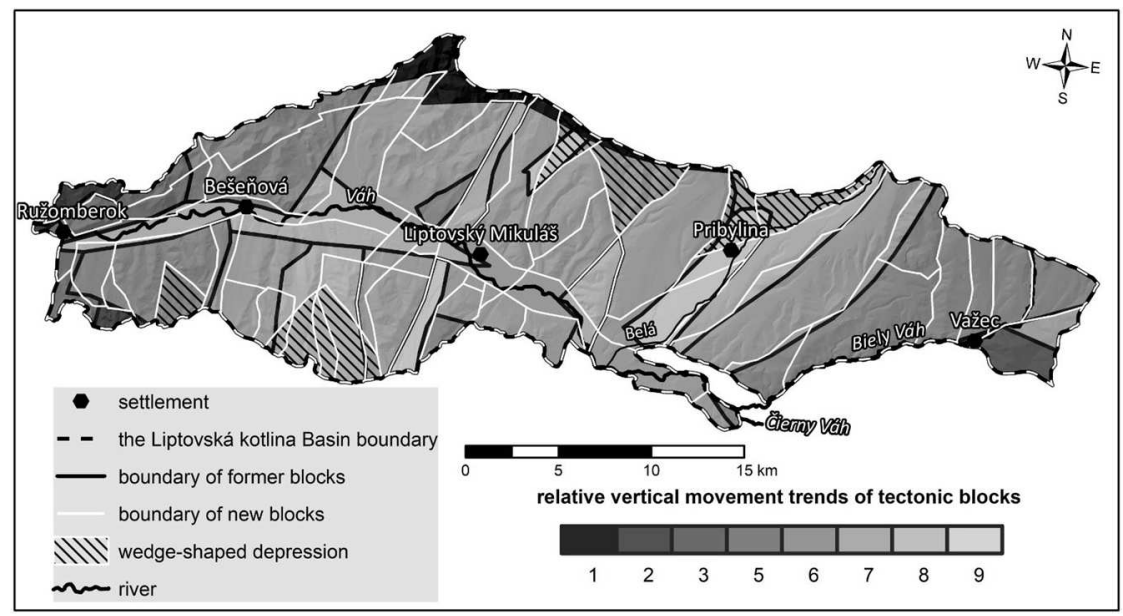

Fig. 9. Neotectonic subdivision and relative vertical movement trends of the LKB according to Maglay et al. (1999) and new boundaries of blocks suggested in this study (white lines)

Vertical movement trends: 1 to 5 uplift: 1 - very large, 2 - large, 3 - medium, 5 - very small, 6 to 9 subsidence: 6 - very small, 7 - small, 8 - medium, 9 - large. Note the wedge-shaped young depressions revealed in this study (hatched polygons)

\section{Neotectonic subdivision}

The LKB was divided into 60 blocks with probably different neotectonic activity (Fig. 9). The majority of the LKB area is subsiding compared with the adjacent mountains. The rivers (mainly the Váh and Belá Rivers) but also some of the Váh 
River tributaries flow through the most subsiding blocks. The presence of wedgeshaped depressions alternating with linear-shaped depressions was identified in the marginal parts of the LKB.

The entire LKB is probably formed by tectonic depressions and elevations as a result of normal faulting and a general W-E to WNW-ESE extension.

\section{DISCUSSION}

The presented analysis reveals more detailed differentiation of the neotectonic blocks in comparison with the previous published studies (e.g. Maglay et al. 1999). In regard to new methods and data, several new features of neotectonic activity were revealed.

As the alpine terrace chronology comprises many limitations (Šujan 2015), no terrace level has been characterised with any age term. The classification of terraces is based on the identification of their bedrock heights from the rich drill and outcrop documentation, considering the previous terrace studies. The terrace levels were divided into 11 levels (following the morphoposition) almost in agreement with Halouzka (1986). On the other hand, 7 (Mazúrová 1978) or 9 terrace levels (Droppa 1970) of the Váh River were identified in the LKB too. The revealing of more levels (11) was caused by the compilation of previous research of the terraces, more detailed research and our own field investigation. A reduced number of levels is also possible in the case that the blocks are even more neotectonically dislocated. There is a possibility of faulting, which was not revealed by this study (e.g. faults undetected with applied methods). However there are several discrepancies in the terrace chronology in the LKB integrating the previous studies of terraces. For instance, within the plateau terrace (VIII), 3 individual levels could be distinguished according to Droppa (1964). But vertical differentiation of the remnants could be caused by the tectonic dislocation as well. More detailed field research including relative dating, but namely numerical dating of fluvial sediments (both are in process) would clarify the fluvial system formation and allow the assessment of the rate of block movements. The asymmetry of terraces (matched or unmatched) preservation, can point to the differentiated erosion of a river (dominance of downcutting or lateral cutting) (Janočko 2004, Goudie 2004) but also to tectonic tilting (Marple and Talwani 2000).

The boreholes and geophysical investigations tend to be used for a study of sedimentary cover also in other areas (e.g. Sebe et al. 2008, Maglay et al. 2009 and Holec et al. 2015). The same method of distinguishing the terraces levels (by means of boreholes analysis) was utilised in other regions as well (e.g. Šujan and Rybár 2014 and Holec 2015). Owing to a dense points database (boreholes, geophysical points), the knowledge about the Quaternary deposits thickness and terraces levels of LKB was specified. Compared to a former Quaternary thickness map (Maglay et al. 2009), the most important finding is the new glacifluvial materialfilled depression revealed SW of Pribylina (Fig. 5). We presume that the depression points to the notable Quaternary subsidence.

According to Halouzka et al. (1999), the older neotectonic activity is represented by $\mathrm{N}-\mathrm{S}$ faults (mainly in the western portion of the LKB) which can be demonstrated until the Lower/Middle Pleistocene alluvial sediments accumulation. The migration of three streams (Jalovec, Smrečianka and Trnovec) into the subsiding blocks was probably caused by the creation of a younger fault system (NE-SW, 
ENE-WSW directions) during the last glacial (c.f. Halouzka et al. 1999) in the central part of the LKB. In the entire LKB, the younger faults were active repeatedly, but in the most expressed way they were active at the beginning of the younger part of the Middle Pleistocene (before the middle terraces formation) (Halouzka et al. 1999). According to our results, several remnants (e.g. SW of Liptovský Mikuláš, SE of Ružomberok) of middle Pleistocene terraces (Fig. 4) are dislocated (tilted and faulted) by NNE-SSW faults, which is the evidence of continuous young tectonic activity.

The location and age of travertine accumulations enables the precise geochronology of the block movement tendencies. As the accumulations preferentially lie on fractures (Hancock et al. 1999), their location allows the evaluation of the time span of tectonic control on travertine formation. Based on the dating of oldest travertines (750 - $600 \mathrm{ka}$ in Čerená village (Franko 2001), 750 - $350 \mathrm{ka}$ an inactive quarry in Bešeňová village (Gradziński et al. 2015), or 450 - 350 ka in Lúčky village - Skaličky (Franko 2001), tectonic activity in the western part of the LKB can be specified since the Middle Pleistocene Age. As younger (Holocene) travertines are located on the same faults, the fault activity can be presumed till recent. Pleistocene and Holocene travertines lie on the faults striking N-S, but W-E too (Ludrová and Bešeňová localities). It points to the continuous neotectonic activity of faults with a W-E direction which was presumed to be the older course of faults (senzu Gross 1980). The similar character of Quaternary fault activity is observed in relation with the Vikartovce fault in the Kozie chrbty Mts. and the Hornádska kotlina Basin (Vojtko et al. 2011). In the LKB, there is a distinctive fault striking approximately W-E of Ružomberok towards to Bešeňová village (Fig. 7), which is expressed in geology and morphology, by travertine accumulations and a wind gap feature, which points to neotectonic activity (Littva 2017 and personal communication).

The asymmetry of drainage network (Fig. 8) can be a marker of the relatively young tilting of particular neotectonic blocks, considering the low order of tilted streams.

The entire LKB was evaluated to be repeatedly relatively subsiding (compared to the adjacent mountains) during the Quaternary. However, the terrace system formation suggests an absolute uplift of the territory. Relatively the largest subsidence was assessed in the area along the Belá River and two other localities in the central part of the LKB (Maglay et al. (1999), Fig 9). The wedge-shaped blocks located on the periphery of the LKB together with linear-shaped blocks revealed within the study are considered to be young tectonic depressions, even though according to Škvarček (1968) the depression SE of Bešeňová is of erosional origin. They are bounded by faults and covered predominantly with Upper Riss to Holocene (proluvial, fluvial and glacifluvial) deposits. Limits of linear depressions situated NW and SW of Liptovský Mikuláš truncate the 3rd upper and 2nd middle terraces. Within these blocks, the block situated NE of Liptovský Mikuláš is considered to be the oldest one, covered by Mindel fluvial deposits. Next to this block, Würm deposits cover the majority of the depression. This suggests the much younger tectonic subsidence, which is in accordance with Halouzka et al. (1999). Wedgeshaped depressions in the south (SW and SE of Bešeňová) are covered mainly by Riss sediments, which also points out to relatively young deformations. The morphotectonic analyses reveal that the depression located SE of Bešeňová consists of 
several partial blocks. This could suggest the local hierarchical neotectonic structure of the mentioned part of the LKB resulting from a changed stress field (Pešková and Hók 2008 and Littva et al. 2015).

\section{CONCLUSION}

Several new inventories, compilations and analyses were carried out in order to summarise the previous geological, geomorphological and geophysical investigations to make the former neotectonic subdivision (Maglay et al. 1999) of the LKB more precise.

The entire heterogeneous terrace system classification of the LKB was unified using a compilation of the previous investigations (Droppa 1964, 1970 and 1972, Banský and Tužinský 1971, Vaškovský and Ložek 1972, Gross 1979, Vaškovský 1980, Páleník 1988, Maglay 1993, Halouzka et al. 1997, Pristaš 1997, Vrábl'ová et al. 1990 and Littva 2017), extensive borehole database and our own field survey.

The summarization of all the published research of tectonic faults was carried out too. New potential faults were delineated (in form of morpholineaments) and the SL index was calculated as a base (fundament) for a new and more precise delimitation of the neotectonic blocks with their diverse movement trends.

The database of boreholes (hydrogeological, engineering-geological, drillings of wells - 1,958 points) and geophysical profiles (predominantly the localities of electrodes $-1,085$ points) from various sources (in the archive of the SGIDS) was created to specify the former evaluation of the spatial distribution of the Quaternary deposits thickness (Maglay et al. 2009) including the identification of new areas with significant subsidence.

The neotectonic subdivision of the LKB (Maglay et al. 1999) was refined on the basis of previous mentioned analyses and summarizations. On the whole, the course of the previous border lines was improved and a number of new boundaries dividing former blocks (Maglay et al. 1999) was delineated including some new wedge-shaped young depressions. A new subdivision comprises of 60 partial blocks compared to 24 blocks from the previous subdivision (Maglay et al. 1999).

The research was supported by the Slovak Research and Development Agency under the contract No. APVV-15-0054, by the Scientific Grant Agency of the Ministry of Education, Science, Research and Sport of the Slovak Republic and the Slovak Academy of Sciences (VEGA) under the contract No. 1/0602/16, and by the Comenius University in Bratislava under the contract No. UK/170/2017.

\section{REFERENCES}

ABAFFY, D., LUKÁČ, M. (1991). Priehrady a nádrže na Slovensku. Bratislava (Alfa).

BANDURA, P., MINÅR, J., DRAGUT, L., HARCINÍKOVÁ, T. (2017). Evaluation of object-based image analysis for morphostructural subdivision of the Western Carpathians. Zeitschrift für Geomorphologie, 61, Suppl. 2, 121-135.

BANSKÝ, V., TUŽINSKÝ, Á. (1971). Účelová hydrogeologická mapa Liptovskej kotliny 1:50 000. Liptovská kotlina - vyhl'adávací hydrogeologický prieskum. Zilina (IGHP, n. p., závod Žilina).

BELLA, P., HAVIAROVÁ, D., KOVÁČ, L., LALKOVIČ, M., SABOL, M., SOJÁK, M., STRUHÁR, V., VIŠŇOVSKÁ, Z., ZELINKA, J. (2014). Jaskyne Demänovskej doliny. Liptovský Mikuláš (ŠOP SR, SSJ). 
BELLA, P., HERCMAN, H., GRADZIŃSKI, M., PRUNER, P., KADLEC, J., BOSÁK, P., GŁAZEK, J., GĄSIOROWSKI, N., NOWICKI, T. (2011). Geochronológia vývoja jaskynných úrovní v Demänovskej doline, Nízke Tatry. A ragonit, 16(1-2), 64-68.

BETÁK, J., VOJTKO, R. (2009). Implementácia nástrojov tektonickej geomorfológie v neotektonickom výskume (na príklade pohoria Považský Inovec). Geografický časopis, 61, 29-47.

BIELY, A., BEZÁK, V., BUJNOVSKÝ, A., VOZÁROVÁ, A., KLINEC, A., MIKO, O., HALOUZKA, R., VOZÁR, J., BEŇUŠKA, P., HANZEL, V., KUBEŠ, P., LIŠČÁK, P., LUKÁČ́IK, E., MAGLAY, J., MOLÁK, B., PULEC, M., PUTIŠ, M., SLAVKAY, M. (1997). Vysvetlivky ku geologickej mape Nizkych Tatier. Bratislava (GS SR, Vydavatelstvo Dionýza Štúra).

DROPPA, A. (1963). Paralelizácia riečnych terás a horizontálnych jaskýň. Geologické práce, 64, 93-96.

DROPPA, A. (1964). Výskum terás Váhu v strednej časti Liptovskej kotliny. Geografický časopis, 16, 313-325.

DROPPA, A. (1966). The correlation of some horizontal caves with river terraces. Studies in Speleology, 1, 186-192.

DROPPA, A. (1970). Výskum riečnych terás v zátopovej oblasti Liptovská Mara. In Kufčák, E., ed. Liptov 1. Vlastivedný zborník. Martin (Osveta), pp. 7-34.

DROPPA, A. (1972). Výskum riečnych terás v okolí Ružomberka. In Kufčák, E., ed. Liptov 2. Vlastivedný zbornik. Martin (Osveta), pp. 11-25.

DROPPA, A. (1975). Minerálne pramene Liptova. In Kufčák, E., ed. Liptov 3. Vlastivedný zborník. Martin (Osveta), pp. 49-81.

FODOR, L., BADA, G., CSILLAG, G., HORVÁTH, E., RUSZKICZAY-RÜDIGER, Z., PALOTẢS, K., SÍKHEGYI, F., TIMÁR, G., CLOETINGH, S., HORVÁTH, F. (2005). An outline of neotectonic structures and morphotectonics of the western and central Pannonian Basin. Tectonophysics, 410, 15-41.

FRANKO, O. (2001). Pôvod a vývoj minerálnych a termálnych vôd Slovenska v priestore a čase $\mathrm{z}$ pohl'adu veku travertínov a izotopov $\mathrm{O}, \mathrm{H}$ a ${ }^{14} \mathrm{C}$. Podzemná voda, 7(2), 26-45.

GOUDIE, A. S. (2004). Encyclopedia of geomorphology. Vol. 1. New York (Routledge).

GRADZIŃSKI, M., DULIŃSKI, M., HERCMAN, H., STWORZEWICZ, E., HOLÚBEK, P., RAJNOGA, P., WRÓBLEWSKI, W., KOVÁČ́OVÁ, M. (2008). Facies and age of travertines from Spiš and Liptov regions (Slovakia) - preliminary results. Slovenský kras, 46, 31-40.

GRADZIŃSKI, M., WROBLEWSKI, W., BELLA, P. (2015). Cenozoic freshwater carbonates of the Central Carpathians (Slovakia): facies, environments, hydrological control and depositional history. Guide to field trip B7, 26-28 June 2015, [Online]. Available: https://www.researchgate.net/profile/Wojciech_Wroblewski/publication/280719018 Cenozoic freshwater carbonates of the Central Carpathians Slovakia facies enviro nments hydrological control and depositional history In Haczewski G ed Guidebo ok for field trips accompanying_31st_IAS M/links/55c25c4008aeb975673e 422e.pdf [accessed 21 March 2016].

GROSS, P. (1979). Geologická mapa Liptovskej kotliny 1:50 000. Bratislava (Geologický ústav Dionýza Śtúra).

GROSS, P. (1980). Tektonika. In Gross, P., Köhler, E., Biely, A., Franko, O., Hanzel, V., Hricko, J., Kupčo, G., Papšová, J., Priechodská, Z., Szalaiová, V., Snopková, P., Stránska, M., Vaškovský, I., Zbořil, L., eds. Geológia Liptovskej kotliny. Bratislava (Geologický ústav Dionýza Śtúra), pp. 116-121.

HACK, J. T. (1973). Stream-profile analysis and stream-gradient index. Journal of Research of the U. S. Geological Survey, 1, 421-429.

HALOUZKA, R. (1986). Z nových poznatkov o stratigrafii kvartéru terasových náplavov riek Západných Karpát (Stredné Pohronie, Orava a Turiec). Regionálna geológia Západných Karpát, 21, 167-175. 
HALOUZKA, R. (1987). Stratigrafia a geologicko-paleogeografický vývoj kvartéru v Západných Tatrách a ich predpolí. Čiastková záverečná správa za rok 1987. Bratislava (Geologický ústav Dionýza Śtúra).

HALOUZKA, R. (1993). Neotektonické štruktúry a pohyby (vrchný pliocén - kvartér) vybraných kotlín a dolín slovenských karpát. In Maglay, J., Baňacký, V., Halouzka, R., Horniš, J., Pristaš, J., eds. Geodynamický vývoj regiónov Slovenska v obdobi vrchný pliocén - kvartér. Bratislava (Geologický ústav Dionýza Štúra).

HALOUZKA, R., BEŇUŠKA, P., MAGLAY, J. (1997). Kvartér. In Biely, A., Bujnovský, A., Vozárová, A., Klinec, A., Miko, O., Halouzka, R., Vozár, J., Beňuška, P., Bezák, V., Hanzel, V., Kubeš, P., Liščák, P., Lukáčik, E., Maglay, J., Molák, B., Pulec, M., Putiš, M., Slavkay, M., eds. Vysvetlivky ku geologickej mape Nízkych Tatier 1:50 000. Bratislava (Vydavatel'stvo Dionýza Štúra), pp. 115-127.

HALOUZKA, R., MAGLAY, J., BAŇACKÝ, V., PRISTAŠ, J., JANOČKO, J., HÓK J. (1999). Vysvetlivky k neotektonickej mape Slovenska 1:500 000. Bratislava (GS SR).

HANCOCK, P. L., CHALMERS, R. M. L., ALTUNEL, E., CAKIR, Z. (1999). Travitonics: using travertines in active fault studies. Journal of Structural Geology, 21, 903-916.

HOLEC, J. (2015). Systémy riečnych terás vo vybraných morfoštruktúrnych regiónoch Západných Karpát. Dizertačná práca, Prírodovedecká fakulta Univerzity Komenského, Bratislava.

HOLEC, J., MEDVEĎOVÁ, A., VITOVIČ, L., PROKEŠOVÁ, R. (2015). Neotektonický vývoj Žiarskej kotliny indikovaný geomorfologickou analýzou v prostredí GIS. Geografický časopis 67, 181-195.

HRAŠNA, M. (1997). Seizmotektonická mapa Slovenska. Mineralia Slovaca, 29, 427-430.

IVAN, L. (1943). Výskyty travertínov na Slovensku. Práce Štátneho geologického ústavu, 9. Bratislava (Justitia).

JANÍK, S. (1970a). Správa z geofyzikálnych meraní na lokalite Jalovec (vodné zdroje pre Liptovský Mikuláś). Bratislava (Ústav užitej geofyziky Brno, závod Bratislava).

JANIK, S. (1970b). Správa z geofyzikálnych meraní v oblasti Liptovskej kotliny, hydrogeologický prieskum. Bratislava (Ústav užitej geofyziky Brno, závod Bratislava; archive number of report in archive of Geofond: 23355).

JANOČKO, J. (2004). Geológia kvartéru. Košice (Technická univerzita v Košiciach).

KELLER, E. A., PINTER, N. (2002). Active tectonics: earthquakes, uplift and landscape. $2^{\text {nd }}$ ed. New Jersey (Upper Saddle River).

KOŠECKÝ, E. (1968). Geofyzikálne merania v oblasti Liptovská kotlina. Brno (Ústav užitej geofyziky, závod Bratislava; Príloha č. $2-C$; archive number of report in archive of Geofond: 30411).

KVITKOVIČ, J. (2001). Niekol'ko poznámok geomorfológa k neotektonickej mape Slovenska. Geografický časopis, 53, 381-385.

LACIKA, J. (1993). Morfoštruktúrna analýza Pol’any. Geografický časopis, 45, 233-250.

LACIKA, J. (1997). Morfoštruktúry Kremnických vrchov. Geografický časopis, 49, 19-33.

LITTVA, J. (2017). Geologický vývoj vnútrohorských kotlín Západných Karpát v obdobi pliocénu a kvartéru. Dizertačná práca, Prírodovedecká fakulta Univerzity Komenského, Bratislava.

LITTVA, J., HÓK, J. (2014). Neotectonics of the Inner Western Carpathians: Liptovský Ján area, case study (northern slopes of Nízke Tatry Mts., Slovakia). Acta Geologica Slovaca, 6, 123-134.

LITTVA, J., HÓK, J., BELLA, P. (2015). Cavitonics: using caves in active tectonic studies (Western Carpathians, case study). Journal of Structural Geology, 80, 47-56.

LUKNIŠ, M. (1973). Reliéf Vysokých Tatier a ich predpolia. Bratislava (Vydavatel'stvo SAV).

MAGLAY, J. (1993). Kvartér Chočských vrchov. In Gross, P., Haško, J., Mello, J., Halouzka, R., Nagy, A., Kováč, P., Filo, I., Havrila, M., Maglay, J., Salaj, J., Franko, O., Zakovič, M., Pospíšil, L., Bystrická, H., Köhler, E., Samuel, O., Snopoková, P., eds. 
Geológia južnej a východnej Oravy. Bratislava (Geologický ústav Dionýza Štúra), pp. 145-150.

MAGLAY, J., HALOUZKA, R., BAŇACKÝ, V., PRISTAŠ, J., JANOČKO, J. (1999). Neotektonická mapa Slovenska v mierke 1:500 000. Bratislava (MŽP SR - GS SR).

MAGLAY, J., MORAVCOVÁ, M., KUČERA, M. (2011a). Vysvetlivky ku geologickej mape kvartéru Slovenska 1:500 000. Bratislava (Štátny geologický ústav Dionýza Štúra).

MAGLAY, J. MORAVCOVÁ, M., ŠEFČÍK, P., VLAČIKY, M., PRISTAŠ, J. (2011b). Prehl'adná geologická mapa kvartéru Slovenskej republiky 1:200 000. Bratislava (MŽP SR, Státny geologický ústav Dionýza Štúra).

MAGLAY, J., PRISTAS, J., KUČERA, M., ÁBELOVÁ, M. (2009). Geologická mapa kvartéru - Mapa hrúbky kvartérneho pokryvu, [Online]. Bratislava (Štátny geologický ústav Dionýza Štúra). Available: http://mserver.geology.sk:8399/arcgis/services/WMS/ HKP500/MapServer/WMSServer [accessed 20 January 2016].

MARPLE, R., T., TALWANI, P. (2000). Evidence for a buried fault system in the Coastal Plain of the Carolinas and Virginia - Implications for neotectonics in the southeastern United States. Geological Society of A merica Bulletin, 112, 200-220.

MAZÚR, E., LUKNIŠ, M. (1978). Regionálne geomorfologické členenie SSR. Geografický časopis 30, 101-125.

MAZÚROVÁ, V. (1978). Terasy riek československých Karpát a ich vzt’ah k terasám Dunaja. Geografický ćasopis, 30, 281-296.

MINÁR, J., BIELIK, M., KOVÁČ, M., PLAŠIENKA, D., BARKA, I., STANKOVIANSKY, M., ZEYEN, H. (2011). New morphostructural subdivision of the Western Carpatians: an approach integrating geodynamics into targeted morphometric analysis. Tectonophysics, 502, 158-174.

NEŠVARA, J. (1970). Vztah fluviálních sedimentů a mladých tektonických pohybů Západných Karpat. Kandidátská práce, Katedra inž. geologie Komenského University Bratislava; IGHP, n. p., Žilina.

ONDRÁŠIK, R. (1987). Inžinierskogeologické zhodnotenie tektonickej nerovnorodosti údolia Váhu medzi Ružomberkom a Krpel’anmi. Bratislava (Katedra inž. geol., Prírodoeved. fakulta Univerzity Komenského).

PÁLENÍK, M. (1988). Sprievodná správa $k$ inžinierskogeologickej mape M 1:10 000 Ružomberok. Žilina (IGHP Žilina).

PEŠKOVÁ, I., HÓK, J. (2008). Quaternary dynamics of the Liptovská kotlina Basin inffered from the trabertine deposits disruption and the Váh River terraces assymetry. Mineralia Slovaca, Geovestnik, 40(3-4), 220.

PRISTAŠ, J. (1997). Kvartér. In Polák, M., Bujnovský, A., Kohút, M., Pristaš, J., Filo, I., Havrila, M., Vozárová, A., Vozár, I., Kováč, P., Lexa, J., Rakús, M., Malík, P., Liščák, P., Hojstričová, V., Žáková, E., Siráňová, Z., Boorová, D., Fejdiová, O., eds. Vysvetlivky ku geologickej mape Vel'kej Fatry 1:50 000. Bratislava (Vydavatel'stvo Dionýza Stúra), pp. 104-114.

REMŠ́́K, A., FENDEK, M., KRÁL, M., BODIŠ, D., MICHALKO, J. (1993). Geotermálna energia Liptovskej kotliny. Čiastková záverečná správa. Bratislava (Geologický ústav Dionýza Štúra).

SEBE, K., CSILLAG, G., KONRÁD, G. (2008). The role of neotectonics in fluvial landscape developement in the Western Mecsek Mountains and related foreland basins (SE, Transdanubia, Hungary). Geomorphology, 102, 55-67.

SLADKÝ, J. (1938). Geologia okolia Ružomberka (Vysvetlenie k plánu toho istého názvu). Ružomberok (Nákladom vlastným).

STOLEČNAN, J. (1975). VD Liptovská Mara - geologický dozor. Žilina (IGHP, n. p., závod Žilina).

STRAHLER, A. (1952). Hypsometria (area-altitude). Analysis of erosional topography. Bulletin of the Geological Society of America, 63, 1117-1142. 
SUCHÝ, F. (1986). Jadrové elektrárne, severné Slovensko. Bratislava (Geofyzika, n. p., Brno, závod Bratislava).

SZALAIOVÁ, E., BIELIK, M., MAKARENKO, I., LEGOSTAEVA, O., HÓK, J., STAROSTENKO, V., ŠUJAN, M., ŠEFARA, J. (2008). Calculation of a stripped gravity map with a high degree of accuracy: a case study of Liptovská kotlina basin (Northern Slovakia). Geological Quarterly, 52, 103-114.

SZALAIOVÁ, V., TKÁČOVÂ, H., GROSS, P. (1991). Liptovská kotlina - reinterpretácia geofyzikálnych merani. Bratislava (Geofyzika, š. p.).

ŠKVARČEK, A. (1968). Niekol'ko poznámok ku kvartérno-geomorfologickému vývoju strednej časti Liptovskej kotliny pod Nízkymi Tatrami. Geografický časopis, 20, 354358.

ŠUJAN, M. (2015). Metodika morfostratigrafického členenia riečnych terás na Slovensku: polemika k používaniu alpského glaciálneho členenia. Mineralia Slovaca. Geovestník, 47, 17-19.

ŠUJAN, M., RYBÁR, S. (2014). Vývoj pleistocénnych riečnych terás vo východnej časti Dunajskej panvy. Acta Geologica Slovaca, 6, 107-122.

TUŽINSKÝ, A., BANSKÝ, V. (1968). Ročná správa za rok 1968. Regionálny hydrogeologický prieskum Liptovskej kotliny. Žilina (IGHP, n. p., závod Žilina).

TUŽINSKÝ, A., BANSKÝ, V., GROSS P., HANZEL, V., HLUBOCKÝ, B., HORNUNG, T., JANÍK, S., KOŠECKÝ, E., MUCHA, I., PELIKÁN, V., PETRÁŠS, I. (1971). Liptovská kotlina - hydrogeologický prieskum (paleogén, kvartér). Žilina (IGHP, n. p., Žilina).

URBANEK, J. (2001). Dva pohl'ady na neotektonickú mapu Slovenska. Geografický časopis, 53, 371-380.

URBÁNEK, J., BETÁK, J., JAKÁL, J., LACIKA, J., NOVOTNÝ, J. (2009). Regional geomophological divisions of Slovakia: old problem in new perspectives. Geographia Slovaca, 26, 237-259.

VAŠKOVSKÝ, I. (1970). Kvartér v západnej časti Liptovskej kotliny. Čiastková správa. Bratislava (Geologický ústav Dionýza Štúra).

VAŠKOVSKYY I. (1975). Kvartér v strednej časti Liptovskej kotliny. Čiastková správa. Bratislava (Státny geologický ústav Dionýza Stúra).

VAŠKOVSKY, I. (1980). Geológia kvartérnych sedimentov. In Gross, P., Köhler, E., Biely, A., Franko, O., Hanzel, V., Hricko, J., Kupčo, G., Papšová, J., Priechodská, Z., Szalaiová, V., Snopková, P. Stránska, M., Vaškovský, I., Zbořil, L., eds. Geológia Liptovskej kotliny. Bratislava (Státny geologický ústav Dionýza Štúra), pp. 96-115.

VAŠKOVSKÝ, J., LOŽEK, V. (1972). Stratigrafia kvartéru západnej časti Liptovskej kotliny. Geologické práce, Správy 50, 130-140.

VOJTKO, R., MARKO, F., PREUSSER, F., MADARÁS, J., KOVÁČOVÁ, M. (2011). Late Quaternary fault activity in the Western Carpathians: evidence from the Vikartovce Fault (Slovakia). Geologica Carpathica, 62, 563-574.

VOJTKO, R., PETRO, L., BENOVÁ, A., BÓNA, J., HÓK, J. (2012). Neotectonic evolution of the northern Laborec drainage basin (northeastern part of Slovakia). Geomorphology, 138, 276-294.

VRÁBLOVÁ, A., MARTINČEKOVÁ, T., CHOVAŇÁKOVÁ, J. (1990). Liptovský Hrádok - inžinierskogeologická mapa M 1:10 000. Sprievodná správa. Bratislava (Slovenský geologický úrad); Žilina (IGHP, š. p.).

ZUCHIEWICZ, W. (1998). Quaternary tectonics of the Outer West Carpathians, Poland. Tectonophysics, 297, 121-132. 
Ladislav Vi to vi ̌̌, Jozef Minár

\section{MORFOTEKTONICKÁ ANALÝZA NA SPRESNENIE NEOTEKTONICKÉHO ČLENENIA LIPTOVSKEJ KOTLINY (ZÁPADNÉ KARPATY)}

Liptovská kotlina (LK), ako jedna z najvyššie položených kotlín Západných Karpát, patrí aj medzi neotektonicky vel'mi aktívne celky (obr. 1). Jej prvú neotektonickú regionalizáciu v mierke 1:200 000 vypracoval Halouzka (1993). Táto bola neskôr spresnená a zaradená do Neotektonickej mapy Slovenska (Maglay et al. 1999). Vzhl'adom na rozmery LK $(\sim 60 \times 15 \mathrm{~km})$ a postupujúce geomorfologické a geologické výskumy je možné jej členenie vykonat' aj podrobnejšie. Táto štúdia prezentuje najaktuálnejšiu a najpodrobnejšiu morfotektonickú analýzu LK s ciel'om spresnenia jej neotektonického členenia so zretel'om na vyhraničenie nových, presnejších hraníc čiastkových neotektonických krýh. Metodika výskumu zahŕn̆a analýzu riečnych terás Váhu (obr. 2, 3 a 4), analýzu priestorových zmien v hrúbke kvartérnych sedimentov (obr. 5) a SL index (obr. 6) s ohl'adom na súčasnú morfológiu LK. Pre morfotektonickú analýzu LK bola tiež dôležitá databáza tektonických zlomov (obr. 7), ako aj konštrukcia morfolineamenov, generovanie riečnej siete (s rádmi tokov podl’a Strahlera) a analýza travertínov (obr. 8). Pri posudzovaní hrúbky kvartéru a detekcii bázy terasových úrovní zohrala dôležitú rolu rozsiahla databáza 1958 vrtov a 1085 geofyzikálnych bodov (miesta lokalizácie elektród geofyzikálnych prieskumov). Na analýzu neotektoniky ovplyvňujúcu fluviálny systém LK bolo $\mathrm{z}$ tejto databázy využitých 65 vrtov v súčasnej nive a 127 vrtov a odkryvov v terasách. Na základe relatívnej výšky nad nivou sme identifikovali 11 terasových úrovní, ktoré sme s ciel'om odhalenia neotektonických procesov (v podobe dislokácií) využili znázornením v ich pozdížnom profile (obr. 4). Rozmiestnenie terasových zvyškov vychádzalo z predchádzajúcich publikovaných výskumov a vlastnej terénnej práce. Morfotektonická analýza LK pozostávajúca z čiastkových analýz prejavov neotektonických pohybov vyústila do návrhu podrobnejšieho neotektonického členenia LK pozostávajúceho zo 60 čiastkových blokov (obr. 9). Hranicami novovymedzených blokov sú vybrané zlomy a morfolineamenty. Významným prínosom $\mathrm{k}$ regionálnemu poznaniu je nielen odhalenie výraznej kvartérnej depresie pri Pribyline (hrúbka výplne min. $50 \mathrm{~m}$, obr. 5), ktorú navrhujeme pridat' do zoznamu depresií v Západných Karpatoch (Maglay et al. 2011), ale aj identifikácia morfologických depresií v tvare trojuholníkov, resp. klinov v okrajových častiach LK (obr. 9). 